\title{
A STAPHYLOCOCCAL AGGRESSIN
}

\author{
M. J. Hill \\ Wright-Fleming Institute, \\ St Mary's Hospital Medical School, London
}

DURING the last few years we have been investigating the evolution of the skin lesion that results from the subcutaneous injection of staphylococci on plugs of cotton dust (Noble, 1965; Agarwal, 1967a, $b$ and $c$ ). When tested in this way, some strains of Staphylococcus aureus produce a purulent lesion from a dose as small as 10-100 colony-forming units (c.f.u.), whilst other, less virulent strains must be injected in a dose of $10^{5}-10^{6}$ c.f.u. to produce a lesion. Yet other strains fail to produce a lesion even in doses of this order. Agarwal (1967a) found that, when the mice were challenged with a "non-virulent" strain, there was an immediate influx of oedema fluid and leucocytes into the area around the cotton pellet, and that there was little if any increase in the bacterial count $24 \mathrm{hr}$ after the challenge. When, however, a more "virulent" strain was injected into the mice, there was no oedema or leucocyte response for at least $2 \mathrm{hr}$. This apparently allowed the staphylococci to multiply and, although there was a massive host response later, a necro-purulent lesion developed. Agarwal postulated that virulent staphylococci possess some factor or factors capable of inhibiting the acute inflammatory response.

Many of the extracellular products of staphylococci have been described as " virulence factors ", including $\alpha$-haemolysin (Goshi et al., 1963), free coagulase (Hale and Smith, 1945) and leucocidin (Mudd, Gladstone and Lenhart, 1965); the production of many other substances, both extracellular, e.g., phosphatase (Carrère and Roux, 1954) and egg-yolk factor (Alder, Gillespie and Thompson, 1955), and cell-bound factors, including bound coagulase (clumping factor), the Smith surface antigen (Rogers and Melly, 1961-62) and Fisher's aggressin (Fisher, 1965) have also been associated with pathogenicity.

This paper describes the isolation from staphylococcal cell walls of a factor that increases the severity of lesions produced by a standard dose of Staph. aureus injected subcutaneously in mice. Some studies have been made on its mode of action.

\section{MATERIALS AND METHODS}

Organisms

All the cultures of Staph. aureus used were isolated in this laboratory from hospital specimens, except PS80 (NCTC9789), PS83A (NCTC10039), 1531 the strain used by Dr S. Fisher (see Fisher, 1965) and kindly given to us by him\}, and strain Wood 46 (NCTC7121) which has been widely used for the production of $\alpha$-toxin. Micrococcus hyicus is a strain lacking $\alpha$-toxin and coagulase, but classified as a staphylococcus by Baird-Parker (1963), and Micrococcus 273 is an obligate aerobic coccus.

Received 1 Nov. 1967; accepted 3 Jan. 1968. 
A large number of strains was examined and six were selected that gave the largest necro-purulent lesions when injected subcutaneously without cotton dust at a dose of $10^{6}$ c.f.u.; these, designated "mouse-virulent", were strains PS80, 1531, Orbach, 7625, 7634 and 7641. Five strains were also selected that gave negligible lesions at a dosage of $10^{6}$ c.f.u.; these, designated " mouse non-virulent", were Wood 46, PS83A, 7666, 1340/4, M. hyicus, and Micrococcus 273.

\section{Media and growth conditions}

Cultures were grown, from a 5 per cent. inoculum of an overnight broth culture, in a medium containing 1 per cent. Oxoid no. 2 nutrient broth and 1 per cent. Oxoid yeast extract and were incubated with gentle shaking at $37^{\circ} \mathrm{C}$.

\section{Preparation of cell walls and cell-wall fractions}

Cells were disrupted by Mickle disintegration until no whole cocci were visible in a Gramstained film. The cell walls were sedimented by centrifugation at $6000 \mathrm{~g}$ for $30 \mathrm{~min}$., washed three times in 0.9 per cent. sodium chloride, then three times in distilled water and freezedried.

Cell-wall teichoic acid was extracted by the method of Baddiley et al. (1962). Cell walls from log-phase cultures were suspended at a concentration of $10 \mathrm{mg}$ per $\mathrm{ml}$ in 10 per cent. (w/v) trichloro-acetic acid (TCA) at $4^{\circ} \mathrm{C}$ for $24 \mathrm{hr}$, then re-extracted for $24 \mathrm{hr}$ at $4^{\circ} \mathrm{C}$ with a further volume of TCA. The TCA extracts were pooled and the teichoic acid was precipitated with 2 volumes of ethanol. The precipitate was redissolved in $10 \mathrm{ml}$ of 10 per cent. TCA and precipitated with $20 \mathrm{ml}$ ethanol, washed with ethanol and then with ether, and dried in vacuo.

Jensen's protein antigen was isolated by the method of Löfkvist and Sjöquist (1962). A

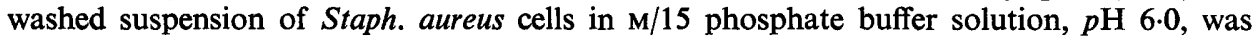
heated at $100^{\circ} \mathrm{C}$ for $30 \mathrm{~min}$., then cooled rapidly to $4^{\circ} \mathrm{C}$. The suspension was centrifuged at $2000 \mathrm{~g}$ for $30 \mathrm{~min}$. at $4^{\circ} \mathrm{C}$, and the supernatant fluid adjusted to $p \mathrm{H} 3.0$ with $0.1 \mathrm{~N}-\mathrm{HCl}$. The precipitate that formed overnight at $4^{\circ} \mathrm{C}$ was removed by centrifugation and dissolved in the phosphate buffer solution $p \mathbf{H}$ 6.0. Ethanol was added to a final concentration of 70 per cent., and the resultant precipitate was spun down and redissolved in phosphate buffer solution of $p \mathrm{H} \mathrm{6.0.} \mathrm{The} \mathrm{antigen} \mathrm{was} \mathrm{further} \mathrm{purified} \mathrm{by} \mathrm{precipitation} \mathrm{from} \mathrm{phosphate} \mathrm{buffer}$ solution with 2 per cent. TCA, then twice with 70 per cent. ethanol, and freeze-dried.

Mucopeptide was isolated by the method of Krause and McCarty (1961). The centrifuged deposit from 1 litre of broth culture was extracted with $10 \mathrm{ml}$ of formamide at $160^{\circ} \mathrm{C}$ for $15 \mathrm{~min}$. After centrifugation at $6000 \mathrm{~g}$ for $30 \mathrm{~min}$., the sediment was washed with distilled water and then extracted in the same way with two further samples of formamide. The residue after extraction was washed carefully, trypsinised as described below, and was freezedried after further extensive washing in saline and distilled water.

Fisher's cell-wall aggressin was prepared by the method described by Fisher (1965). This procedure involves treatment of cells with $4 \mathrm{M}$ urea for $3 \mathrm{hr}$, Mickle disintegration, and treatment of the isolated cell walls with 0.1 per cent. sodium lauryl sulphate followed by extraction of the residue with 10 per cent. TCA.

Deoxycholate fractionation of cell walls was carried out as described previously (Hill, 1967). Cell walls were suspended in 1 per cent. deoxycholate solution at a concentration of $5 \mathrm{mg}$ per $\mathrm{ml}$ and held at $4^{\circ} \mathrm{C}$ for $6 \mathrm{hr}$. The suspension was centrifuged at $6000 \mathrm{~g}$ for $30 \mathrm{~min}$., and the insoluble residue was washed twice in 0.9 per cent. sodium chloride solution and then three times in distilled water and was freeze-dried (DOCR). The deoxycholate extract was passed through a column of G-50 Sephadex to remove the deoxycholate and other low molecular weight substances, leaving a solution of high molecular weight material. This was freeze-dried.

\section{Treatment of cell walls with enzymes and other agents}

Lysozyme (crystalline, from Koch-Light Ltd) was used at $p \mathrm{H} 7.0$ and $37^{\circ} \mathrm{C}$ at the concentration and for the times specified in the text. Trypsin (crystalline, from Koch-Light Ltd) was used at $p \mathrm{H} 8.2$ and at $37^{\circ} \mathrm{C}$ for $1 \mathrm{hr}$ at a concentration of 0.001 per cent. 
Cell walls were treated with formaldehyde at a concentration of 2 per cent. for $8 \mathrm{hr}$ at room temperature and with periodate at a concentration of $0.1 \mathrm{M}$ at room temperature for $2 \mathrm{hr}$.

\section{Measurements of lesions}

Enhancement of lesions. The various fractions isolated from the staphylococci were tested for their ability to enhance the production of a lesion by injecting them subcutaneously together with a dose of staphylococci (strain PS80) that, by itself, was too small to produce a visible lesion. This is similar to the test system described by Fisher (1963). Agarwal's lesion-scoring system (1967a) was used, but cotton dust was not used in these experiments.

Exudation of oedema fluid. After a number of preliminary tests in which the oedema produced in response to staphylococci on cotton dust was measured by direct weighing, a simpler system was adopted in which cotton dust was injected without live staphylococci. The normal response to such an injection is a rapid exudation of fluid into the surrounding tissue and this can readily be demonstrated by the intravenous injection of Evans blue. Plugs of cotton dust impregnated with the test material were therefore injected subcutaneously and immediately afterwards $0.1 \mathrm{ml}$ of a 1 per cent. solution of Evans blue (Boots Pure Drug Co. Ltd) was injected intravenously; this dye is fixed to the plasma albumin and so can be used to detect areas of increased vascular permeability. The animals were subsequently killed with chloroform and the flap of skin and subcutaneous tissue in which the lesion develops was reflected; the area of blue coloration around the lesion could then be measured. Cotton plugs alone elicit a blue zone that is of an easily measurable size $3 \mathrm{hr}$ after injection; the lesions were therefore examined after $3 \mathrm{hr}$. A zone size smaller than that due to cotton alone indicated inhibition of oedema exudation, whilst an area larger than the control indicated increased vascular permeability. Results were expressed in terms of an oedema index, I, where

$$
I=\frac{\text { area of blue zone due to the test material and cotton dust. }}{\text { area of blue zone due to cotton dust alone. }}
$$

Viable count of staphylococci at the lesion site

The viable count of staphylococci at the lesion site was determined by the method of Agarwal (1967a).

\section{Analytical methods}

Analytical methods were described previously (Hill).

\section{RESULTS}

\section{Enhancement of lesions by staphylococcal cell walls}

The effect of cell-wall material from a range of strains on the severity of the lesion produced by the subcutaneous injection of $10^{5} \mathrm{c.f}$.u. of PS80 staphylococci was investigated. Cell-wall material from " mouse non-virulent" strains had no effect on the severity of the lesion even when as much as $400 \mu \mathrm{g}$ was used. Material from log-phase cultures of " mouse-virulent" strains, on the other hand, injected together with the $10^{5}$ cocci gave rise to large erythematous nodular lesions at a dosage level of $50 \mu \mathrm{g}$ and gave rise to easily detectable lesions at a level of $20 \mu \mathrm{g}$ (table I). Cell walls of mouse-virulent strains seemed to possess a factor, absent from mouse non-virulent strains, that participated in the lesion-forming process. The cell walls were therefore fractionated to isolate this factor. 


\section{Enhancement of lesions by cell wall fractions}

Staphylococcal cell walls consist mainly of mucopeptide, teichoic acid and protein, together with small amounts of polysaccharide and variable amounts of lipid. Mucopeptide, teichoic acid and Jensen's protein antigen were isolated

\section{TABLE I}

Variation in the lesion score with the amount of cell-wall material added to the standard dose of PS80 staphylococci injected subcutaneously into mice

\begin{tabular}{|c|c|c|c|c|c|c|}
\hline \multirow{2}{*}{\multicolumn{2}{|c|}{ Test strain }} & \multicolumn{5}{|c|}{$\begin{array}{c}\text { Mean lesion score }{ }^{*} \text { for the test material at the following } \\
\text { dose levels } \dagger(\mu \mathrm{g})\end{array}$} \\
\hline & & 400 & 200 & 100 & 50 & 20 \\
\hline $\begin{array}{l}\text { Ward 52A } \\
\text { PS80 . } \\
1531 . \\
7634 . \\
\text { Wood } 46 \\
\text { PS83A } \\
7666 .\end{array}$ & $\dot{\dot{.}} \dot{\dot{.}} \dot{.}$ & $\begin{array}{l}4.5 \\
5.6 \\
3.6 \\
0.7 \\
1.0 \\
1.4\end{array}$ & $\begin{array}{l}3 \cdot 5 \\
\ldots \\
\ldots \\
1 \cdot 2 \\
0 \\
\ldots\end{array}$ & $\begin{array}{l}2 \cdot 3 \\
3 \cdot 2 \\
2 \cdot 3 \\
0 \\
0 \cdot 4 \\
1 \cdot 0\end{array}$ & $\begin{array}{l}2.0 \\
2.7 \\
\ldots \\
0 \\
0.4 \\
\ldots\end{array}$ & $\begin{array}{l}2.0 \\
1.5 \\
2.0 \\
1.6 \\
0.7 \\
0.6 \\
0.4\end{array}$ \\
\hline
\end{tabular}

* Lesion scores are the mean values for batches of 6 mice.

$\dagger$ The lesion score in the absence of added test material was $0 \cdot 5-1 \cdot 0$.

TABLE II

Variation in the lesion score with the amount of cell-wall fraction added to the standard dose of PS80 staphylococci injected subcutaneously into mice

\begin{tabular}{|c|c|c|c|c|c|c|c|}
\hline \multirow{2}{*}{$\begin{array}{c}\text { Test } \\
\text { strain }\end{array}$} & \multirow{2}{*}{$\begin{array}{l}\text { Cell-wall } \\
\text { fraction }\end{array}$} & \multicolumn{6}{|c|}{$\begin{array}{l}\text { Mean lesion score * for the test fraction at the following } \\
\text { dose levels } \dagger(\mu \mathrm{g})\end{array}$} \\
\hline & & 100 & 50 & 20 & 10 & 5 & 2 \\
\hline PS80 & $\begin{array}{l}\text { Fisher } \\
\text { aggressin }\end{array}$ & $\ldots$ & $\ldots$ & $1 \cdot 8$ & $\ldots$ & $\ldots$ & $\ldots$ \\
\hline $\begin{array}{l}\text { PS80 } \\
\text { PS80 } \\
1531 \\
1531 \\
7634 \\
7581 \\
\text { Wood } 46 \\
7666 \\
\text { PS83A }\end{array}$ & $\begin{array}{l}\text { DOCR } \\
\text { DOC extract } \\
\text { DOCR } \\
\text { DOC extract } \\
\text { DOCR } \\
\text { DOCR } \\
\text { DOCR } \\
\text { DOCR } \\
\text { DOCR }\end{array}$ & $\begin{array}{l}\ldots \\
\ldots \\
\cdots \\
\ldots \\
\cdots \\
0.7 \\
0 \\
1.0\end{array}$ & $\begin{array}{l}3 \cdot 3 \\
\ldots \\
3 \cdot 3 \\
\ldots \\
3 \cdot 2 \\
3 \cdot 5 \\
0 \\
0 \cdot 6 \\
1 \cdot 0\end{array}$ & $\begin{array}{l}2 \cdot 3 \\
1 \cdot 2 \\
2 \cdot 6 \\
0 \\
1 \cdot 7 \\
1 \cdot 8 \\
0 \\
0 \cdot 6 \\
1.0\end{array}$ & $\begin{array}{l}1.7 \\
\ldots \\
2 \cdot 2 \\
\ldots .8 \\
0.8 \\
2 \cdot 2 \\
0 \cdot 7 \\
0 \\
\ldots\end{array}$ & $\begin{array}{l}1.8 \\
\ldots \\
1.7 \\
\ldots \\
1.8 \\
0.5 \\
0 \\
0.6 \\
\ldots\end{array}$ & $\begin{array}{l}1.0 \\
\ldots \\
\ldots \\
\ldots \\
1.0 \\
\ldots \\
\ldots \\
\ldots\end{array}$ \\
\hline
\end{tabular}

* Lesion scores are the mean values for batches of 6 mice.

$\uparrow$ The lesion score in the absence of added test material was $0 \cdot 5-1 \cdot 0$.

from a log-phase culture of PS80. None of these fractions stimulated lesion production at a dose of $100 \mu \mathrm{g}$. This might have been because they are not involved in lesion enhancement or because the active principle had been destroyed during the isolation procedures. 
The fraction prepared by Fisher's method from strain PS80 gave good lesion enhancement when tested at a dose level of $20 \mu \mathrm{g}$ (table II), but attempts to purify it further were unfruitful.

The deoxycholate extract from the mouse-virulent strains PS80 and 1531 had no lesion-potentiating effect, but as little as $5 \mu \mathrm{g}$ of the residue after extraction with deoxycholate (DOCR) of log-phase cultures of these and other " mouse-virulent" strains when injected with $10^{5}$ staphylococci of PS80 led to easily detectable lesions. Severe necrotic lesions were produced when the dose was raised to $50 \mu \mathrm{g}$. DOCR from " mouse non-virulent" strains had no effect on the severity of the lesion even at a dose level of $100 \mu \mathrm{g}$ (table II).

Treatment of DOCR with lysozyme released the active factor into solution, but if the enzymic treatment was prolonged the solubilised factor was destroyed.

TABLE III

Variation in the lesion-enhancing activity of the residue after extraction with deoxycholate with the age of the culture

\begin{tabular}{|c|c|c|c|c|c|c|}
\hline \multirow{2}{*}{ Strai } & & \multicolumn{5}{|c|}{$\begin{array}{l}\text { Mean lesion score * for the standard dose of PS } 80 \text { cells together } \\
\text { with } 20 \mu \mathrm{g} \text { of DOCR from cultures of the following age } \dagger(\mathrm{hr})\end{array}$} \\
\hline & & 3 & 7 & 16 & 24 & 40 \\
\hline $\begin{array}{l}\text { PS80 } \\
1531\end{array}$ & : & $\begin{array}{l}2 \cdot 3 \\
2 \cdot 6\end{array}$ & $\begin{array}{l}1 \cdot 2 \\
1 \cdot 3\end{array}$ & 0 & $\begin{array}{l}1 \cdot 0 \\
0 \cdot 7\end{array}$ & $\begin{array}{l}0 \cdot 3 \\
0\end{array}$ \\
\hline $\begin{array}{l}\text { Wood } 46 \\
\text { PS83A }\end{array}$ & : & $\begin{array}{l}0 \cdot 8 \\
1 \cdot 1\end{array}$ & $\begin{array}{l}0.4 \\
1 \cdot 0\end{array}$ & $\begin{array}{l}0 \cdot 4 \\
1 \cdot 0\end{array}$ & $\begin{array}{l}0 \cdot 4 \\
\cdots\end{array}$ & $\begin{array}{l}0.4 \\
1 \cdot 0\end{array}$ \\
\hline
\end{tabular}

The optimum conditions for obtaining the active factor in solution were treatment with 50 i.u. per ml of lysozyme for $6 \mathrm{hr}$, followed by lyophilisation of the supernatant after centrifugation. Since the active factor was resistant to heat at $100^{\circ} \mathrm{C}$ for $10 \mathrm{~min}$., the lysozyme in the solution could be inactivated by heat treatment before lyophilisation. The activity of the soluble factor was unaffected by treatment with trypsin, formaldehyde or periodate.

\section{Lesion-enhancing activity of DOCR derived from cultures of various ages}

Only DOCR derived from logarithmically dividing cultures had high lesionenhancing activity (table III). Samples were harvested from a growing culture at various times during the growth cycle; DOCR was prepared from these samples and tested for lesion-enhancing activity. The injection of $20 \mu \mathrm{g}$ of DOCR from cells of PS80 or 1531 harvested in the mid-logarithmic phase of growth, together with the $10^{5}$ c.f.u. of staphylococci PS80 gave rise to large necro-purulent lesions, whilst DOCR from cells harvested during the stationary phase had little or no lesion-enhancing activity. DOCR from cells of Wood 
46 or PS83A had no lesion-enhancing activity regardless of the age of the culture from which it was derived.

\section{Composition of the DOCR}

Table IV gives the results of chemical analyses of the cell wall and the deoxycholate residue for strains PS80 and 1531. As reported earlier (Hill), the DOCR contains no detectable phosphorus or lipid and very little polysaccharide, and consists almost entirely of mucopeptide and protein.

TABLE IV

Macromolecular composition of the cell wall and DOCR of staphylococcal strains PS80 and 1531

\begin{tabular}{c|c|c|c|c|c|c}
\hline \multirow{2}{*}{ Strain } & \multirow{5}{*}{$\begin{array}{c}\text { Cell-wall } \\
\text { fraction }\end{array}$} & \multicolumn{5}{|c}{ Percentage composition } \\
\cline { 3 - 7 } & Mucopeptide & $\begin{array}{c}\text { Teichoic } \\
\text { acid }\end{array}$ & Lipid & Protein & Polysaccharide \\
\cline { 3 - 7 } PS80 & cell wall & 25 & 25 & 4 & 24 & 1 \\
& DOCR & 70 & $<1$ & 0 & 14 & 1 \\
& cell wall & 30 & 30 & $\ldots$ & 14 & 1 \\
& DOCR & 75 & $<1$ & $\cdots$ & 10 & 1 \\
\hline
\end{tabular}

The effect of DOCR on the viable count of Staph. aureus during the course of lesion formation

Viable counts made during the course of lesion formation after the subcutaneous injection of $10^{5}$ c.f.u. of PS80 alone indicated an initial decrease in the number of colony-forming units (fig. 1), followed by a slow increase to a level roughly equal to the initial count. At $24 \mathrm{hr}$ the viable count was $10^{4}$, and there was practically no visible lesion. When the same number of organisms was injected together with $20 \mu \mathrm{g}$ DOCR derived from a 3-hr culture of PS80, the viable count again decreased during the $1 \mathrm{st} \mathrm{hr}$, but to a smaller extent than in the absence of DOCR, and later increased rapidly to reach a count of $10^{7}$ after $24 \mathrm{hr}$. The visible lesion was nodular and erythematous and was approximately $5 \mathrm{~mm}$ in diameter. Thus the presence of DOCR markedly reduced the initial killing of the staphylococci and allowed them to multiply at a faster rate than in the control lesion.

The effect of DOCR on the exudation of oedema fluid during the course of lesion formation

The effect of DOCR on the exudation of oedema fluid was tested by measuring the size of the blue zone $3 \mathrm{hr}$ after injection. When injected together with DOCR from the "mouse non-virulent" strains, the cotton plug was 
surrounded by a blue zone with an area of $30-50$ sq. mm, 2-3 times that of the lesion due to cotton alone (i.e., the DOCR had an oedema index, I, of 2-3). When DOCR from log-phase cultures of the "mouse virulent" strains was used, the index was $0.3-0.5$ (table V). Thus there was a clear distinction between DOCR from "virulent" and " non-virulent" strains, the former inhibiting and the latter increasing the oedema exudation. There was also stimulation of the exudation of oedema fluid by DOCR from walls of other organisms, such as Bacteroides spp., Lactobacillus spp., E. coli and Ps. aeruginosa, which did not produce skin lesions under the conditions of these tests.

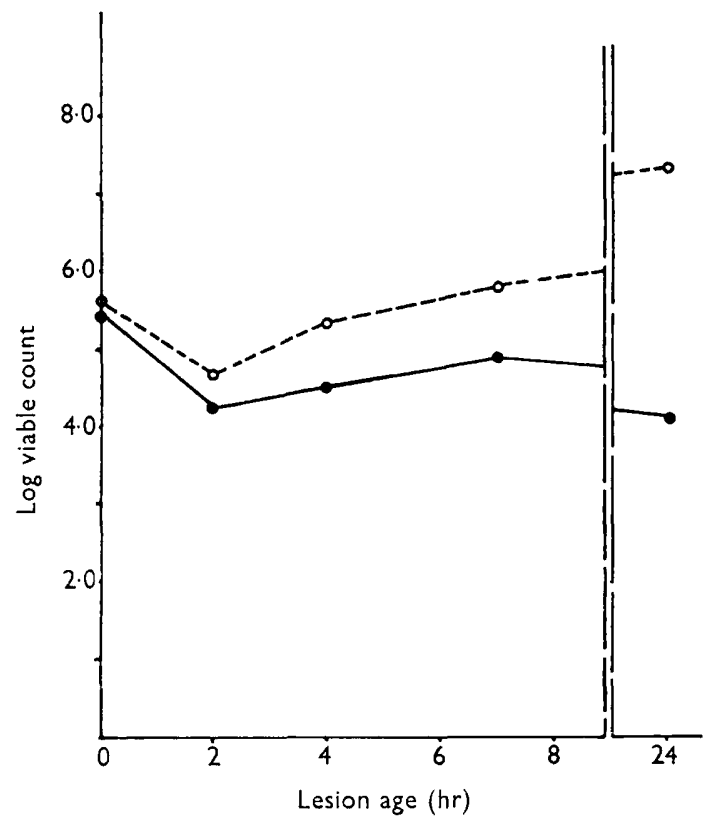

FIG. 1.-The effect of the residue after extraction with deoxycholate (DOCR) on the viable count of Staphylococcus aureus in the course of lesion formation.

- Viable counts in mice infected with $10^{5}$ c.f.u. of PS80 staphylococci on plugs of cotton dust.

○ ... O Viable counts in mice infected with $10^{5}$ c.f.u. of PS80 staphylococci together with $20 \mu \mathrm{g}$ of DOCR from PS80 staphylococci on plugs of cotton dust.

The cultures initially tested had been selected as being either highly virulent or definitely non-virulent and it was possible that, although a clear distinction existed between such strains, a random sample of staphylococci might have an effect on oedema exudation that is normally distributed about a mean. For this reason, 100 separately isolated cultures of Staph. aureus were selected at random; DOCR was prepared from log-phase cultures of each and tested for its effect on the exudation of fluid following injection on a cotton pellet (fig. 2). The oedema indices of the strains were distributed bimodally; there was either strong inhibition or strong stimulation of oedema exudation, and very few strains were found to have no effect. 
Variation in oedema index of DOCR with the age of the culture from which it was derived

The effect of DOCR on the oedema response depended on the age of the culture from which the material was derived (fig. 3). "Mouse-virulent" strains

TABLE V

Oedema response to DOCR from some " mouse virulent" and some "mouse non-virulent" strains of Staph. aureus and other cocci

\begin{tabular}{|c|c|c|}
\hline Strain & & Oedema index I \\
\hline $\begin{array}{lll}\text { Mouse-virulent } & \text { strains } \\
\text { PS80 } & : & : \\
1531 & : & : \\
\text { Orbach } & : & : \\
7625 & : & : \\
7634 & : & :\end{array}$ & $\begin{array}{l}\cdot \\
:\end{array}$ & $\begin{array}{l}0 \cdot 32 \\
0 \cdot 37 \\
0 \cdot 38 \\
0 \cdot 39 \\
0 \cdot 40\end{array}$ \\
\hline $\begin{array}{l}\text { Mouse non-virulent str } \\
\text { Wood 46 } \\
\text { PS83A } \\
7666 \text {. } \\
\text { Micrococcus hyicus } \\
\text { Micrococcus 273 }\end{array}$ & $\begin{array}{l}: \\
:\end{array}:$ & $\begin{array}{l}2 \cdot 62 \\
2 \cdot 77 \\
2 \cdot 82 \\
2 \cdot 50 \\
3 \cdot 64\end{array}$ \\
\hline
\end{tabular}

The values for I are derived from the mean zone area for batches.

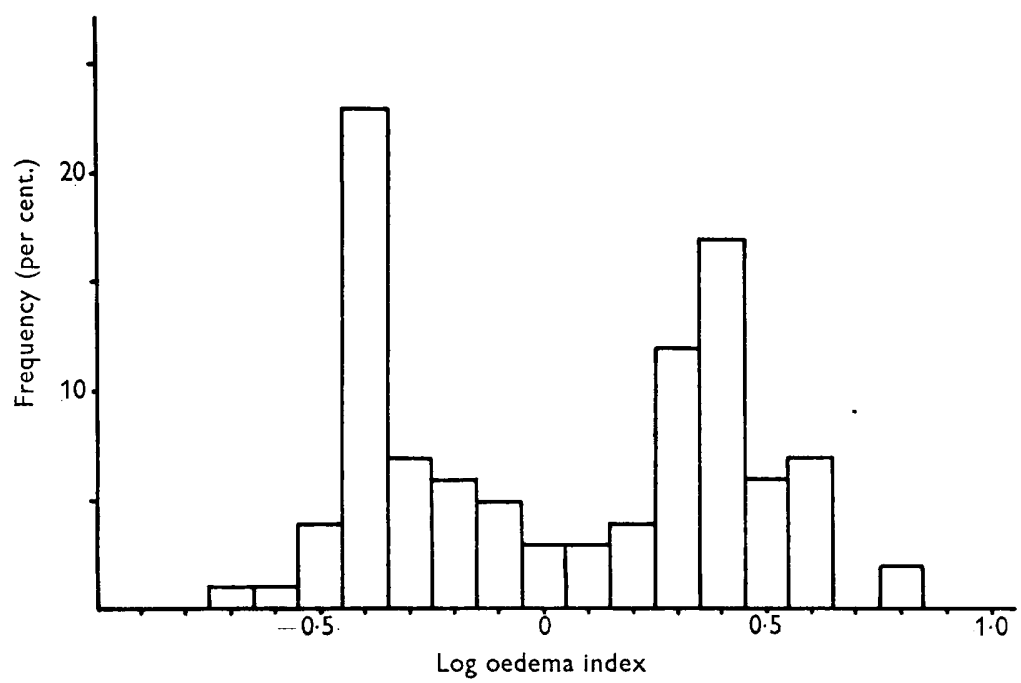

Fig. 2.-Percentage distribution of oedema indices of 100 separately isolated cultures of Staphylococcus aureus.

yielded an oedema-inhibiting factor that was at its maximum concentration during the phase of logarithmic growth, but DOCR from 24-hr cultures of PS80 and 1531 had no effect on oedema exudation; in this way the effect on oedema production ran parallel with lesion-enhancing activity. With strain 
Orbach the change during the growth cycle was even more marked; DOCR from log-phase cultures inhibited the oedema response, whilst that from 24-hr cultures stimulated it. With DOCR from avirulent strains there was a uniform stimulation of oedema regardless of the phase in the growth cycle.

The oedema-inhibiting factor was unaffected by periodate, formaldehyde, trypsin or heat at $100^{\circ} \mathrm{C}$ for $10 \mathrm{~min}$. It was released into solution by lysozyme, but was destroyed by more prolonged treatment with the enzyme. In all of these respects it behaved similarly to the lesion-enhancing factor.

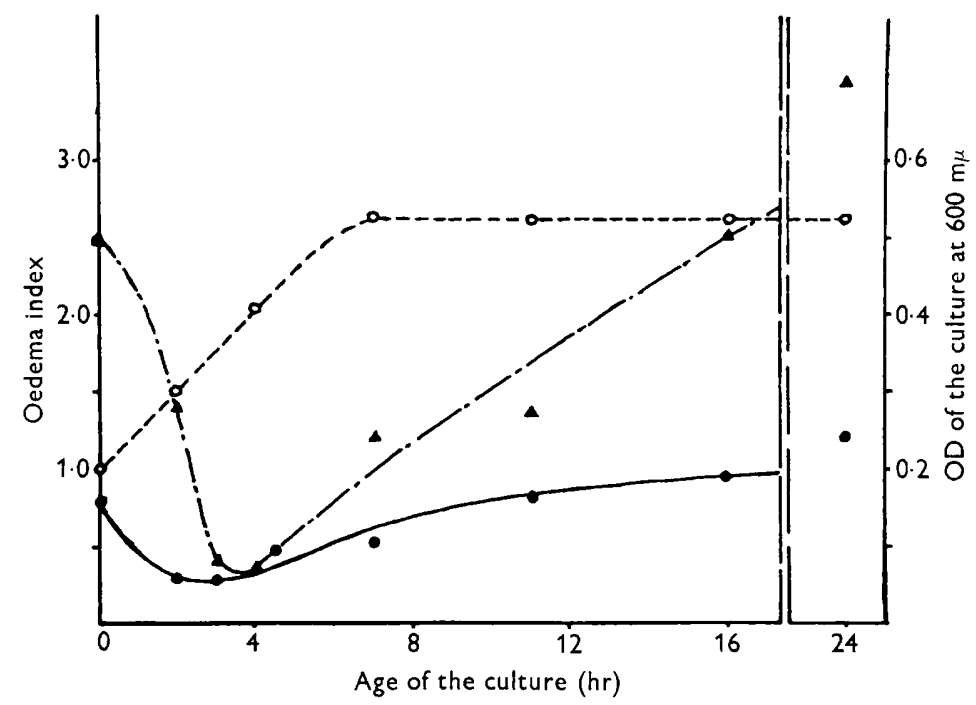

FIG. 3.-Variation in the oedema index of DOCR with the age of the culture from which it was derived.

O -.. O Variation in $\mathrm{OD}_{600}$ with age for the various staphylococcal strains.

$\Delta-\rightarrow \Delta$ Variation in oedema index with age for strain Orbach.

Variation in oedema index with age for strain PS80.

\section{Discussion}

Fisher (1965) has shown that a cell-wall factor can be isolated from " mousevirulent" staphylococci that has a lesion-enhancing effect. We extracted a similar factor by a different procedure and were able to obtain it in soluble form. This may prove helpful in determining more exactly the chemical nature of the factor. Our findings to date indicate that the DOCR is a mucopeptideprotein complex. Since the material responsible for lesion enhancement is unaffected by trypsin treatment and by formyl blocking of amino groups, and since it is destroyed by treatment with lysozyme, there is a strong indication that the mucopeptide is involved. If this is confirmed, the variation with age of culture of lesion-enhancing and oedema-inhibiting activity would indicate that there was a variation in the composition or structure of the mucopeptide layer of the cell wall during the growth cycle. Such a variation in mucopeptide structure has not previously been suspected.

From his work on staphylococcal skin lesions in mice, Agarwal (1967c) 
postulated that a virulent strain must inhibit the leucocyte migration and the oedema exudation at the lesion site, and must also produce a full range of toxins and enzymes, in order to take full advantage of this delayed response of the host-defence mechanism. The results reported here would support this view. The cultures selected as being "mouse virulent" all possessed the DOCR factor, which inhibits oedema exudation whilst the "mouse non-virulent" cultures all lacked this factor. According to Agarwal's postulate many cultures that inhibited the exudation of oedema fluid might still be " non-virulent" if they did not inhibit leucocyte migration or did not produce a sufficient quantity or range of toxic products. Those strains that did not inhibit oedema exudation, however, should all be non-virulent, since an early oedema response, even in the absence of an early leucocyte response, was found by Agarwal to be sufficient to prevent the development of a purulent lesion.

\section{SUMMARY}

Cell walls from "mouse-virulent" strains of Staphylococcus aureus were found to have " aggressin " activity; the addition of isolated cell walls to a dose of staphylococci that was too low to produce any lesion on subcutaneous injection alone led to the formation of a large necro-purulent lesion. Cell walls from " mouse non-virulent" strains did not enhance lesion production in this way. A method of isolating the lesion-enhancing material from the cell walls of mouse-virulent strains is described. This material consists mainly of mucopeptide with some protein but no teichoic acid. It is resistant to heating at $100^{\circ} \mathrm{C}$ for $10 \mathrm{~min}$., to tryptic digestion, and to treatment with periodate or formaldehyde, but is rendered soluble and subsequently destroyed by lysozyme.

The lesion-enhancing material, when injected subcutaneously into mice on a plug of cotton dust, inhibits the accumulation of oedema fluid at the site of injection. The corresponding cell-wall fraction isolated from mouse nonvirulent strains not only failed to inhibit but even stimulated the exudation of oedema fluid.

I thank the Medical Research Council for financial support during this work, and Miss Jennifer Lambert for her excellent technical assistance.

\section{REFERENCES}

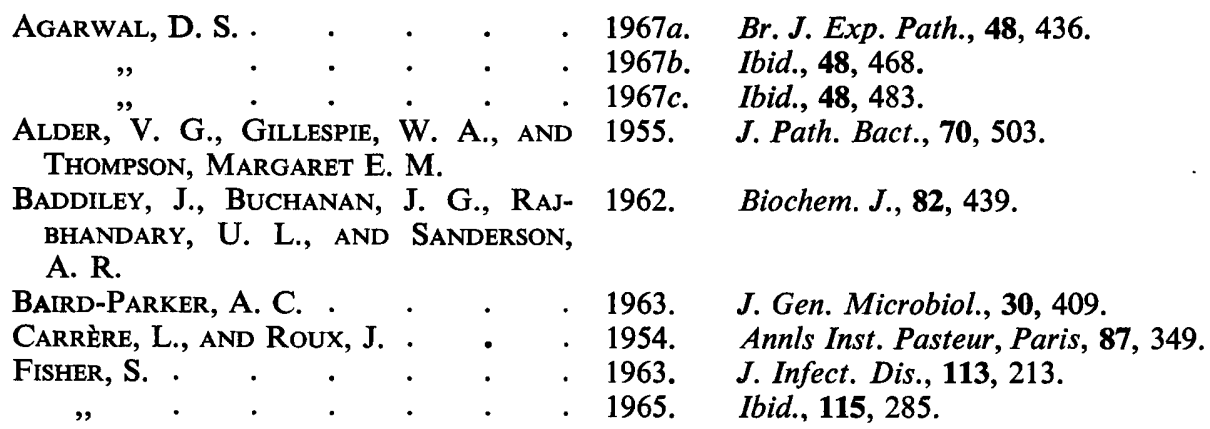


Goshi, K., Smith, E. W., Cluff, L. E., 1963. Bull. Johns Hopk. Hosp., 113, 183. AND NoRMAN, P. S.

Hale, J. H., ANd Smith, W. . $\quad$ - $\quad$ - 1945. Br. J. Exp. Path., 26, 209.

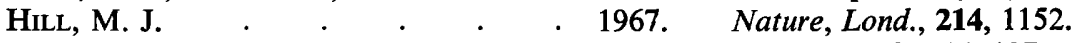

Krause, R. M., AND MCCarty, M. . 1961. J. Exp. Med., 114, 127.

LöFKVIST, T., AND SJöQUIST, J. - · 1962. Acta path. microbiol. scand., 56, 295.

Mudd, S., Gladstone, G. P., AND 1965. Br. J. Exp. Path., 46, 455.

LENHART, N. A.

NoBLE, W. C.

- $1965 . \quad$ Ibid., 46, 254.

Rogers, D. E., ANd Melly, Marian A. 1961-62. Yale J. Biol. Med., 34, 560. 